\title{
Final Height and Its Predictive Factors after Renal Transplantation in Childhood
}

\author{
A. C. S. HOKKEN-KOELEGA, M. A. E. van ZAAL, W. van BERGEN, M. A. J. DE RIDDER, \\ T. STIJNEN, E. D. WOLFF, R. C. J. W. DE JONG, R. A. DONCKERWOLCKE, \\ S. M. P. F. DE MUINCK KEIZER-SCHRAMA, AND S. L. S. DROP
}

Department of Pediatrics, Division of Endocrinology and Nephrology, Sophia Children's Hospital/Erasmus University, Rotterdam |A.C.S.H.-K., M.A.E.v.Z., W.v.B., E.D.W., S.M.P.F.d.M.K.-S., S.L.S.D.]; Radboud Hospital, Nijmegen (R.C.J.W.d.J.]; Wilhelmina

Children's Hospital, Utrecht [R.A.D.]; and Department of Epidemiology and Biostatistics, Erasmus University Rotterdam, The Netherlands (M.A.J.d.R., T.S.]

\section{ABSTRACT}

A retrospective study is reported assessing final height (FH) and its predictive factors in 52 patients $(31$ male, 21 female) who underwent renal transplantation (RTx) before the age of $15 \mathrm{y}$. They received prednisone daily or on alternate days as well as azathioprine. The study period covered $20 \mathrm{y}$. FH remained below the third height percentile [height standard deviation score for chronologic age $\left(\mathrm{hSDS}_{\mathrm{CA}}\right)<-1.88$ ] for most of these patients (77\% males, $71 \%$ females). Median (range) $\mathrm{FH}$ was 165.0 (143.0-176.8) $\mathrm{cm}$ in males and $153.0(135.0-168.4) \mathrm{cm}$ in females. Median difference between FH and target height was 15.0 and 15.4 $\mathrm{cm}$ for males and females, respectively. For both sexes, the median $\mathrm{hSDS}_{\mathrm{CA}}$ was already below -1.88 at the start of the first hemodialysis, after which it decreased significantly until the first RTx. After RTx, there was no significant improvement of hSDS ${ }_{\mathrm{CA}}$. The predictive factors for $\mathrm{FH}$ were determined by evaluating various factors simultaneously in a multiple regression analysis. This analysis provided a regression equation for predicting $\mathrm{FH}$. A higher $\mathrm{hSDS}_{\mathrm{CA}}$ at the time of the first RTx and alternate-day versus daily prednisone therapy both had a significantly positive influence on $\mathrm{FH}$, whereas a longer duration of reduced GFR $\left(<50 \mathrm{~mL} / \mathrm{min} / 1.73 \mathrm{~m}^{2}\right)$ had a significantly negative effect on $\mathrm{FH}$. Other factors such as age or bone age at first RTx, primary renal disease, duration of initial dialysis, repeat $\mathrm{RTx}$, and the cumulative dose of prednisone did not influence FH significantly. In conclusion, $71-77 \%$ of patients that received their first renal transplant before the age of 15 ended up with severely short adult stature. Optimization of the $\operatorname{hSDS}_{\mathrm{CA}_{\mathrm{A}}}$ at first RTx appears very important. Long-term administration of prednisone on alternate days would then result in optimal FH, particularly if the GFR remains above $50 \mathrm{~mL} / \mathrm{min} / 1.73 \mathrm{~m}^{2}$. (Pediatr Res 36: 323-328, 1994)

FH, final height

Abbreviations

RTx, renal transplantation

hSDS $_{\mathbf{C A}}$, height standard deviation score for chronologic age

HD, hemodialysis

AD, alternate-day
Growth failure is a common and serious consequence of chronic renal failure in childhood. The majority of these children now survive thanks to advances in hemodialysis and RTx, but successful transplantation rarely results in full growth rehabilitation. Some children show an appreciable improvement in growth after RTx, but the initially increased growth rate may not be sustained during the ensuing years of immunosuppressive drug administration (1). Van Diemen-Steenvoorde et al. (2) reported that the FH of one third of patients who underwent RTx

Received October 21, 1993; accepted February 4, 1994.

Correspondence and reprint requests: A. C. S. Hokken-Koelega, Department of Pediatrics, Division of Endocrinology, Sophia Children's Hospital, Dr. Molewaterplein 60, 3015 GJ Rotterdam, The Netherlands.

Supported by Novo Nordisk, Denmark. before a bone age of $16 \mathrm{y}$ in boys and $14 \mathrm{y}$ in girls remained more than $2 \mathrm{SD}$ score below the mean. The psychosocial consequences of short stature are profound in both children and adults. Recent studies have convincingly shown that recombinant hGH therapy will accelerate growth significantly both before $(3,4)$ and after RTx $(5,6)$. For a true evaluation of this therapy, it is essential to assess $\mathrm{FH}$ and pinpoint its predictive factors in patients not so treated.

We carried out a retrospective analysis of patients who received their first $\mathrm{RTX}$ before the age of 15 in the Netherlands during the past $20 \mathrm{y}$. We evaluated their height at the start of the first HD, at the first RTx, and at attainment of $\mathrm{FH}$. In addition, we assessed the impact of several factors on $\mathrm{FH}$. 


\section{METHODS}

From February 1972 to May 1990, 212 patients under $15 \mathrm{y}$ of age received their first functioning renal allograft at one of the three pediatric centers involved in this study. This number represents $95 \%$ of all Dutch children who underwent a first RTx (95\% cadaveric allografts) during this period and excludes those with renal allografts that ceased to function within $3 \mathrm{~d}$ after RTx. Of these 212 patients, 149 were suitable for growth analysis, and the remaining 63 were excluded because 18 of them died within $1 \mathrm{y}$ after RTx, records were incomplete for 25 of them, six underwent androgen therapy before RTx, eight suffered from either cystinosis or oxalosis, and six refused access to their data. For the purpose of the present study, we included a cohort of 52 patients, 32 males who were born before July 1970 and 21 females born before July 1972. The study period ran until July 1992.

Evaluation consisted of data from the start of the first dialysis through attainment of FH or the end of the study period. At each examination, the following items were recorded: height, weight, sexual maturation, serum creatinine, episodes of HD and number of RTx, prednisone regimen and dose $(\mathrm{mg} / \mathrm{kg} / \mathrm{d})$, type and dose of immunosuppressive drugs, occurrence of acute or chronic rejection episodes (diagnosed by a renal biopsy, increased serum creatinine, fever, hypertension, decreased urine output, or renal scintigraphy), and bone age if appropriate. The primary renal disease and parental height were also noted.

Height was measured by experienced persons using the Harpenden stadiometer and expressed as $\operatorname{hSDS}_{\mathrm{CA}}$. Height standards for healthy Dutch children were used as reference data (7). Bone age was determined from radiographs of the left hand and wrist using the method of Greulich and Pyle (8). Pubertal maturation was recorded according to Tanner and Whitehouse's stage (9). Determination that $\mathrm{FH}$ had been attained was based on radiography showing epiphyseal closure of the hand and wrist and completion of pubertal maturation with a height increment remaining under $0.5 \mathrm{~cm} / \mathrm{y}$. At the end of the study period, all but two male patients had achieved $\mathrm{FH}$. Both boys were growing less than $0.5 \mathrm{~cm} / \mathrm{y}$, but one of them was still prepubertal at $25 \mathrm{y}$ of age, and the other one had not yet reached a late pubertal stage at age 26 . They had reached heights of 158.0 and $143.0 \mathrm{~cm}$, and these were considered their FH. Parental height served to calculate target height for each patient individually, with the exception of one adopted child. Secular trend was taken into account: father's height plus mother's height \pm $12 \mathrm{~cm} / 2,+3 \mathrm{~cm}(10)$. Target height in centimeters was converted into target height $\operatorname{SDS}_{\mathrm{CA}}$, using Dutch standards for FH (7). GFR was determined using the method described by Morris et al. (11) and expressed as $\mathrm{mL} / \mathrm{min} /$ $1.73 \mathrm{~m}^{2}$.

All patients received immunosuppressive medication; azathioprine was used in combination with prednisone starting immediately after RTx. None of the study pa- tients received cyclosporine. All patients started receiving prednisone on the day of RTx at an initial dose of 3.0 $\mathrm{mg} / \mathrm{kg} / \mathrm{d}$. For 44 patients, this dose was tapered off to 2.0 $\mathrm{mg} / \mathrm{kg} / \mathrm{d}$ during the second postoperative week and to 1.0 $\mathrm{mg} / \mathrm{kg} / \mathrm{d}$ from the third week. From 3 mo until the end of the first year after RTx, prednisone administration was then reduced to a maintenance dose. Until 1978, this maintenance dose amounted to $0.30 \mathrm{mg} / \mathrm{kg} / \mathrm{d}$, and from 1978 it was $0.15 \mathrm{mg} / \mathrm{kg} / \mathrm{d}$. For the remaining eight patients, the initial dose of $3.0 \mathrm{mg} / \mathrm{kg} / \mathrm{d}$ was tapered off gradually to a maintenance dose of $0.40 \mathrm{mg} / \mathrm{kg} / \mathrm{d}$ from 3 mo post-RTx until 1978 and after that to $0.20 \mathrm{mg} / \mathrm{kg} / \mathrm{d}$. Before 1977 , all children received daily prednisone. In 1977, some patients were changed to AD therapy, and from 1983 onward $50 \%$ of all patients received AD prednisone, starting at 3 mo after RTx in the aforementioned group of 44 patients and at $1 \mathrm{y}$ after RTx in the remaining eight patients. None of the study patients had overt signs of renal osteodystrophy, either before or after RTx.

Acute rejection episodes were treated with either 20 $\mathrm{mg} / \mathrm{kg}$ i.v. methylprednisolone on $\mathrm{AD}$ for a period of 10-14 d or oral prednisone in an initial dose of 200 $\mathrm{mg} / 1.73 \mathrm{~m}^{2}$, which was reduced every $3 \mathrm{~d}$ to taper off completely in the course of $15 \mathrm{~d}$. Four patients received eight i.v. injections of antithymocyte globulin $(4 \mathrm{mg} / \mathrm{kg})$ in one course of $21 \mathrm{~d}$.

For each individual patient, we calculated the cumulative dose of prednisone $(\mathrm{mg} / \mathrm{kg})$, the percentage of time on AD therapy (\%AD), and the total duration (years) of a reduced GFR (defined as GFR $<50 \mathrm{~mL} / \mathrm{min} / 1.73 \mathrm{~m}^{2}$ ) from the start of the first RTx until FH.

Two-sample $t$ test was used to assess differences between two groups. To study the influence of a number of variables on FH after RTx, we carried out a simple linear regression analysis, involving the association between a continuous variable and the $\mathrm{FH}$, whereby each variable was considered singly. To determine the influence on $\mathrm{FH}$ of several variables simultaneously, we then carried out multiple regression analyses. This first involved a stepwise, backward elimination procedure on the variables known at the time of the first RTx, i.e. sex $(1=$ female $)$, duration of initial dialysis period (years), primary renal disease $(1=$ urinary tract abnormalities, renal hypoplasia, or both; 2 = glomerulopathies and other renal diseases; 3 = nephrotic syndrome), chronologic and bone

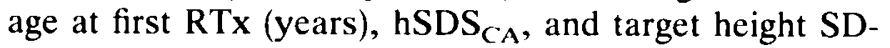
$S_{C A}$. Next, the model was extended in a forward selection manner, also stepwise, adding the posttransplant variables, i.e. cumulative dose of prednisone (counted per $100 \mathrm{mg} \cdot \mathrm{kg}$ ), \%AD prednisone, and length of time (years) that GFR remained below $50 \mathrm{~mL} / \mathrm{min} / 1.73 \mathrm{~m}^{2}$, all concerning FH after RTx.

\section{RESULTS}

Clinical data of the 52 study patients are summarized in Table 1. The primary renal disease was divided into congenital disorders, i.e. urinary tract abnormalities, re- 
Table 1. Clinical data of 52 study patients*

\begin{tabular}{|c|c|c|}
\hline & $\begin{array}{c}\text { Male } \\
(n=31)\end{array}$ & $\begin{array}{l}\text { Female } \\
(n=21)\end{array}$ \\
\hline \multicolumn{3}{|l|}{ First dialysis } \\
\hline Age at start $(y)$ & $11.0(6.7-14.8)$ & $10.2(3.7-13.8)$ \\
\hline Duration $(y)$ & $0.8(0.2-5.6)$ & $1.2(0.3-2.8)$ \\
\hline \multicolumn{3}{|l|}{ Renal transplant } \\
\hline \multicolumn{3}{|l|}{ Age $(y)$ at } \\
\hline RTX 1 & $\begin{array}{c}11.8(7.2-14.5) \\
\quad(n=31)\end{array}$ & $\begin{array}{c}11.7(5.0-14.5) \\
(n=21)\end{array}$ \\
\hline RTx 2 & $\begin{array}{c}17.2(13.3-20.8) \\
\quad(n=6)\end{array}$ & $\begin{array}{l}16.0(11.2-17.5) \\
\quad(n=2)\end{array}$ \\
\hline RTx 3 & $21.0(n=1)$ & $\begin{array}{l}17.3(15.4-19.3) \\
\quad(n=2)\end{array}$ \\
\hline \multicolumn{3}{|l|}{ Prednisone therapy } \\
\hline \multicolumn{3}{|l|}{$\begin{array}{l}\text { Percentage of time on AD } \\
\text { prednisone (\%AD) }\end{array}$} \\
\hline $0 \%(n)$ & 10 & 8 \\
\hline $10-60 \%(n)$ & 7 & 5 \\
\hline$>60 \%(n)$ & 14 & 8 \\
\hline \multicolumn{3}{|l|}{$\begin{array}{l}\text { GFR during study period } \\
\text { from first RTx to FH }\end{array}$} \\
\hline$>50 \mathrm{~mL} / \mathrm{min} / 1.73 \mathrm{~m}^{2}$ & 17 & 8 \\
\hline$<50 \mathrm{~mL} / \mathrm{min} / 1.73 \mathrm{~m}^{2}$ & 14 & 13 \\
\hline Duration (y) & $4.3(1.6-9.4)$ & $3.4(0.2-6.6)$ \\
\hline $\begin{array}{l}\text { Duration of study period from } \\
\text { first RTx to FH (y) }\end{array}$ & $8.2(5.0-14.3)$ & $7.0(3.0-13.6)$ \\
\hline
\end{tabular}

nal hypoplasia, or both in 18 patients and other disorders such as glomerulopathy in 34 patients. All study patients had hemodialysis before their first RTx and none underwent peritoneal dialysis. Forty-one patients in the study group received only one RTx, eight had a second, and three had a third RTx. The GFR of 25 patients $(48 \%, 17$ boys and eight girls) was satisfactory ( $>50 \mathrm{~mL} / \mathrm{min} / 1.73$ $\mathrm{m}^{2}$ ) from the first RTx through $\mathrm{FH}$. However, 27 patients $(52 \%)$ had a reduced GFR $\left(<50 \mathrm{~mL} / \mathrm{min} / 1.73 \mathrm{~m}^{2}\right)$ at some time during the study period with a median duration of $4.3 \mathrm{y}$ in boys and $3.4 \mathrm{y}$ in girls.

$F H$. Median (range) hSDS ${ }_{\mathrm{CA}}$ of the patients is given in Table 2, at initiation of HD, at the first RTx, and at attainment of FH. FH is shown in centimeters in comparison with target height. It appeared that the median height for all patients was already below the third percentile for height $\left(<-1.88 \mathrm{hSDS}_{\mathrm{CA}}\right)$ at the start of the first HD. A significant mean (SD) decrease of $\mathrm{hSDS}_{\mathrm{CA}}$ occurred during HD (Wilcoxon's signed-rank test, $p<$
$0.0001)$, amounting to $-0.6(0.6)$ in boys and girls alike. There was no difference between the median $\mathrm{hSDS}_{\mathrm{CA}}$ at first RTx and at FH. The median FH for males was 165.0 $\mathrm{cm}$ and for females, $153.0 \mathrm{~cm}$, which fell far short of their median target height of 180.0 and $168.4 \mathrm{~cm}$, respectively. This median target height for both male and female patients was comparable with the median FH of the Dutch reference population (182.0 and $168.4 \mathrm{~cm}$, respectively) (7). The difference between FH and target height in the study population amounted to $15.0 \mathrm{~cm}$ for males and 15.4 $\mathrm{cm}$ for females. FH was attained at a median (range) age of $21.0(18.0-23.0) \mathrm{y}$ in males and $18.75(16.25-22.0) \mathrm{y}$ in female patients.

Figure 1 illustrates the $\operatorname{hSDS}_{\mathrm{CA}}$ of each individual patient at various time points. It is apparent that the hSDS $_{\mathrm{CA}}$ at the start of the first RTx did not improve during the ensuing years. The $\mathrm{FH}$ of $77 \%$ of male patients and $71 \%$ of female patients remained below the third height percentile $\left(<-1.88\right.$ hSDS $\left._{\mathrm{CA}}\right)$.

Impact of various factors on $\mathbf{F H}$. Simple linear regression analysis revealed a significant negative association between FH and the following variables: $\operatorname{sex}(p<0.0001)$ and duration of GFR $<50 \mathrm{~mL} / \mathrm{min} / 1.73 \mathrm{~m}^{2}$ after the first RTx $(p=$ 0.01 ). A significant positive association was found for the variables $\mathrm{hSDS}_{\mathrm{CA}}$ at the start of HD and at the first RTx ( $p$ $=0.04$ and $p=0.02$, respectively) and \%AD prednisone ( $p$ $=0.005$ ). Factors that proved to be insignificant when analyzed individually were age and bone age at first RTx, primary renal disease, duration of initial HD period, target height $\operatorname{SDS}_{\mathrm{CA}}$, number of RTx, and cumulative dose of prednisone from the first RTx until FH.

The backward multiple regression analysis performed on the variables known at the time of the first RTx resulted in a model containing sex and the $\mathrm{hSDS}_{\mathrm{CA}}$ at the first RTx. Subsequently, stepwise forward selection including posttransplant variables revealed the following predictive factors: percentage of time on $\mathrm{AD}$ prednisone and duration of a reduced GFR $\left(<50 \mathrm{~mL} / \mathrm{min} / 1.73 \mathrm{~m}^{2}\right)$. The results of this multiple regression model, given in Table 3, provided the following equation for predicting FH in patients who received their first RTx in childhood: Predicted FH $(\mathrm{cm})=174.85-12.4 \times \operatorname{sex}+3.9 \times$ hSDS $_{\mathrm{CA}}$ at first RTx $+0.05 \times \% \mathrm{AD}-1.4 \times$ posttransplant years with GFR $<50 \mathrm{~mL} / \mathrm{min} / 1.73 \mathrm{~m}^{2}$.

Table 2. Auxologic data of 52 study patients*

\begin{tabular}{|c|c|c|c|c|c|}
\hline & \multicolumn{2}{|c|}{ Height } & \multicolumn{2}{|c|}{$\mathrm{FH}$} & \multirow{2}{*}{$\begin{array}{c}\text { Target height } \\
(\mathrm{cm})\end{array}$} \\
\hline & First dialysis hSDS ${ }_{C_{A}}$ & First RTx hSDS ${ }_{C A}$ & $\operatorname{hSDS}_{\mathrm{CA}_{\mathrm{A}}}$ & $\mathrm{cm}$ & \\
\hline Male $(n=31)$ & $\begin{array}{c}-2.0 \\
(-4.5-0.1) \\
-2.8 \text { to }-1.3 \ddagger\end{array}$ & $\begin{array}{c}-2.6 \dagger \\
(-5.0 \text { to }-0.5) \\
-3.2 \text { to }-1.6 \ddagger\end{array}$ & $\begin{array}{c}-2.5 \\
(-5.8 \text { to }-0.8) \\
-3.1 \text { to }-1.9 \ddagger\end{array}$ & $\begin{array}{c}165.0 \\
(143.0-176.8) \\
161.0-169.3 \ddagger\end{array}$ & $\begin{array}{c}180.0 \\
(173.5-191.0) \\
177.5-183.1 \neq\end{array}$ \\
\hline Female $(n=21)$ & $\begin{array}{c}-1.9 \\
(-4.2-1.8) \\
-2.8 \text { to }-1.3 \ddagger\end{array}$ & $\begin{array}{c}-2.5 \dagger \\
(-4.4-0.8) \\
-2.9 \text { to }-1.5 \ddagger\end{array}$ & $\begin{array}{c}-2.5 \\
(-5.4-0.0) \\
-3.3 \text { to }-1.6 \ddagger\end{array}$ & $\begin{array}{c}153.0 \\
(135.0-168.4) \\
147.6-158.5 \ddagger\end{array}$ & $\begin{array}{c}168.4 \\
(160.5-179.0) \\
163.6-172.4 \ddagger\end{array}$ \\
\hline
\end{tabular}

* Values expressed as median (range).

$\dagger$ Compared with hSDS $\mathrm{CA}_{\mathrm{A}}$ at first dialysis: $p<0.0001$.

$\ddagger$ Interquartile range. 


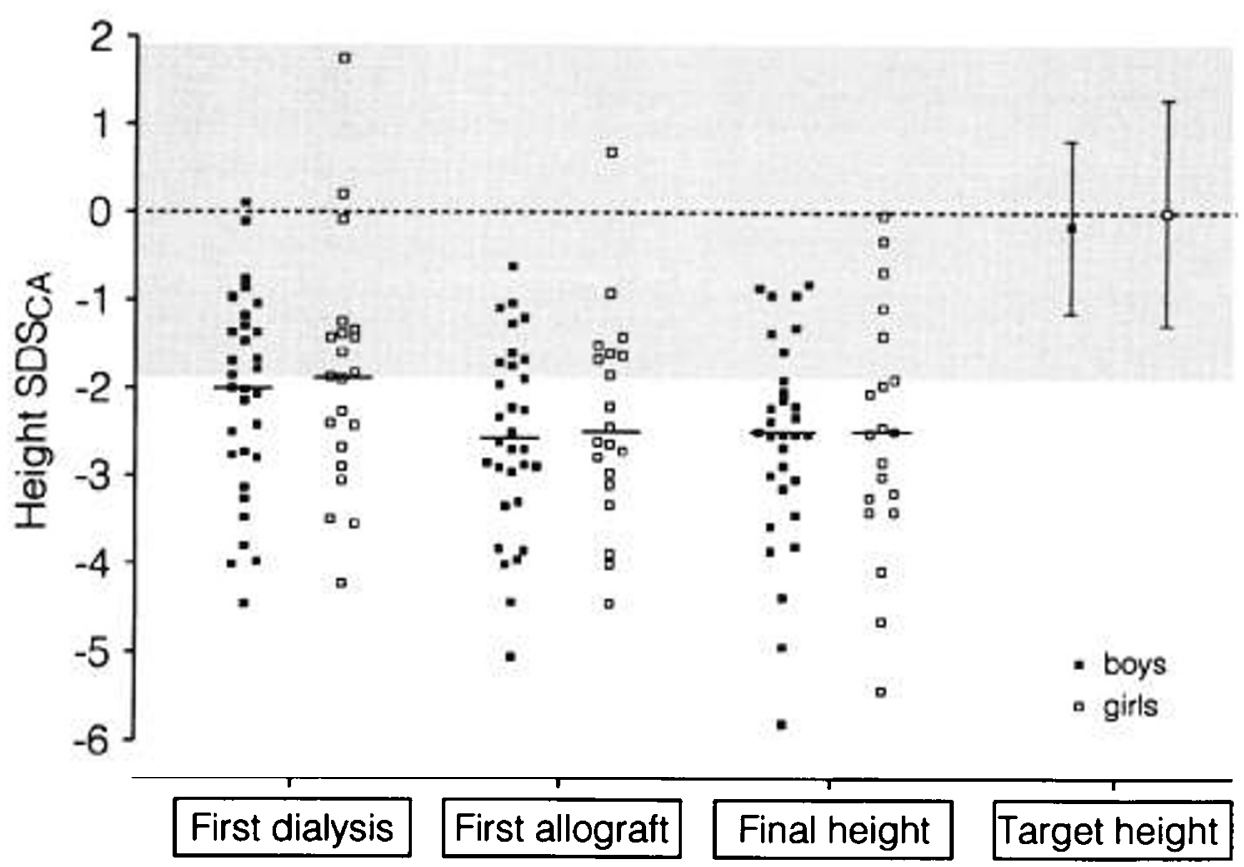

Figure 1. Individual hSDS $\mathrm{CA}_{\mathrm{A}}$ at various time points of the study and median (range) target height in 31 male and 21 female renal allograft patients. The dotted area represents $94 \%$ of the healthy reference population (3rd to 97 th percentile).

The regression coefficient for sex was -12.4 . This means that the difference in $\mathrm{FH}$ between males and females will average $12.4 \mathrm{~cm}$, provided that the other factors are equal. This is fully in accordance with the healthy Dutch reference population (7). The regression coefficient for hSDS $\mathrm{CA}$ at first RTx amounted to 3.9, which means that if two children differ $1 \mathrm{hSDS}_{\mathrm{CA}}$ at the first RTx this will result in an average difference in $\mathrm{FH}$ of $3.9 \mathrm{~cm}$, provided that the other factors are equal. The regression coefficient for duration of reduced GFR was -1.4 , implying that for each additional year that the GFR is less than $50 \mathrm{~mL} / \mathrm{min} / 1.73 \mathrm{~m}^{2}$, FH will be reduced by 1.4 $\mathrm{cm}$, provided that the other factors are equal. The regression coefficient for the percentage of time on AD prednisone was 0.05 , indicating that the $\mathrm{FH}$ of two patients, one receiving prednisone $\mathrm{AD}$ for $80 \%$ and the other $100 \%$ daily $(=0 \% \mathrm{AD})$, will differ $4 \mathrm{~cm}$ on average, provided all other factors remain equal.

None of the other variables, including the cumulative dose of prednisone $(p=0.20)$, were significantly associ-

Table 3. Results of stepwise multiple regression analysis on $\mathrm{FH}^{*}$

\begin{tabular}{|c|c|c|c|}
\hline Variable & $\begin{array}{r}\text { Regression } \\
\text { coefficient }\end{array}$ & SEM & $p$ value \\
\hline $\operatorname{Sex}(0=$ male $; 1=$ female $)$ & -12.4 & 1.5 & $<0.0001$ \\
\hline Height SDS at first RTx & 3.9 & 0.7 & $<0.0001$ \\
\hline $\begin{array}{l}\text { Duration of graft dysfunction (y) } \\
\left(\text { GFR }<50 \mathrm{~mL} / \mathrm{min} / 1.73 \mathrm{~m}^{2}\right)\end{array}$ & -1.4 & 0.3 & $<0.0001$ \\
\hline $\begin{array}{l}\text { Percentage of time on } \mathrm{AD} \\
\text { prednisone }(\% \mathrm{AD})\end{array}$ & 0.05 & 0.02 & 0.0075 \\
\hline
\end{tabular}

* Regression equation: predicted $\mathrm{FH}(\mathrm{cm})=174.85-12.4 \times(\mathrm{sex})+$ $3.9 \times\left(\mathrm{hSDS}_{\mathrm{CA}}\right)-1.4 \times($ duration of graft dysfunction $)+0.05 \times$ (\%AD). ated with FH when added simultaneously with the significant variables in the multiple regression analysis.

\section{DISCUSSION}

Our study shows that most patients who received their first renal graft before the age of $15 \mathrm{y}$ attained a very disappointing $\mathrm{FH}$, surpassing our worst expectations. For $77 \%$ of the men and $71 \%$ of the women, $\mathrm{FH}$ remained below the third height percentile $\left(<-1.88 \mathrm{hSDS}_{\mathrm{CA}}\right)$. Other workers have studied posttransplant growth, but very few examined FH systematically $(2,12)$. Van Diemen-Steenvoorde et al. (2) reported that one third of patients who received an RTx before a bone age of $16 \mathrm{y}$ in boys and 14 in girls had an FH that fell below -2.00 $\operatorname{hSDS}_{\mathrm{CA}}$ (2). The relatively better FH results reported for these studies are probably because these were based on data of selected patients that had attained $\mathrm{FH}$ at a relatively young age and did not include data of patients with delayed pubertal development. Interestingly, our present findings correspond with the results of a previous study indicating that $70 \%$ of the prepubertal children who underwent their first RTx during recent years and were treated with current protocols did not show an appreciable catch-up growth during the first $2 \mathrm{y}$ after RTx (13). This suggests that the findings of this retrospective study on FH may also be valid for patients treated today.

It appeared that the median $\mathrm{hSDS}_{\mathrm{CA}}$ was already below $-1.88 \mathrm{SD}$ at the start of the first dialysis. Subsequently, dialysis led to a significant decrease in $\mathrm{hSDS}_{\mathrm{CA}}$ until the first RTx, after which it did not improve, resulting in a disappointing $\mathrm{FH}$. The median difference between target height and $\mathrm{FH}$ amounted to $15.0 \mathrm{~cm}$ in males and $15.4 \mathrm{~cm}$ females. 
Our study revealed that four factors simultaneously had a significant influence on $\mathrm{FH}$ : sex, $\mathrm{hSDS}_{\mathrm{CA}}$ at the time of the first RTx, percentage of time on AD prednisone, and duration of reduced graft function (GFR $<50$ $\mathrm{mL} / \mathrm{min} / 1.73 \mathrm{~m}^{2}$ ). As for the first factor, the difference in FH between male and female post-RTx patients was comparable with that of the Dutch reference population (7). It therefore appears that $\mathrm{FH}$ is equally affected in males and females.

Until recently, pretransplant growth retardation was beyond control, despite intensive medical care and dialysis. However, during recent years, it has been convincingly shown that biosynthetic growth hormone treatment accelerates pretransplant growth significantly without adverse effects. Growth hormone treatment did not accelerate epiphyseal maturation, although it improved $\mathrm{hSDS}_{\mathrm{CA}}$ at first RTx, thus promising a better $\mathrm{FH}(3,4)$. In view of these positive findings, we prefer biosynthetic growth hormone treatment and do not advocate preemptive RTx for severe growth retardation in these children.

It is particularly interesting that a longer duration of reduced GFR ( $\left.<50 \mathrm{~mL} / \mathrm{min} / 1.73 \mathrm{~m}^{2}\right)$ appeared to have a significant negative effect on FH. Others have observed that reduction in renal graft function was associated with a marked deceleration in growth velocity after RTx (14, 15), but until now no information on its association with FH has been provided. In a previous study in 19 growthretarded renal allograft patients with a mean GFR of 66 $\mathrm{mL} / \mathrm{min} / 1.73 \mathrm{~m}^{2}$, we found a negative correlation between renal graft function and the serum IGF-binding protein-3 levels. This suggests that a reduced GFR may contribute to growth retardation after RTx via increased serum insulin-like growth factor-binding protein levels together with decreased IGF bioavailability $(16,17)$.

The present study clearly demonstrates that long-term administration of prednisone on $\mathrm{AD}$ has a beneficial effect on FH compared with daily administration, even in the presence of other significant factors. The less negative effect of $\mathrm{AD}$ prednisone on statural growth has been reported by others $(18,19)$, but some had contradictory results $(20)$. Information regarding the effect of $A D$ prednisone on long-term growth until $\mathrm{FH}$ is very limited. Reported studies merely compared the growth of children on $\mathrm{AD}$ prednisone with that of children who were on daily prednisone because of mild deterioration of renal function, without differentiating between the effect of either AD or daily therapy coupled with that of other factors. Recently, a prospective and controlled study analyzed the effect of $\mathrm{AD}$ versus daily prednisone therapy on growth during a period of 14-27 mo in a selected group of children with normally functioning renal grafts (21). It was concluded that the inhibitory effect on growth velocity of a certain cumulative dose of prednisone was significantly less when given on $\mathrm{AD}$, without any additional risk of rejection. From these results together with our present findings, one might conclude that AD prednisone administration is preferable to daily administration. Nonetheless, well-controlled, long-term studies re- main important to verify that the $A D$ regimen does not increase the risk of renal graft deterioration.

Other factors such as age or bone age at first RTx, primary renal disease, duration of initial dialysis, repeat RTx, and the cumulative dose of prednisone did not influence FH significantly when analyzed simultaneously with the significant factors. Because all children of this retrospective study were treated in the pre-cyclosporine era, we were not able to evaluate the differential impact of various immunosuppressive regimens. However, in a previous study of prepubertal patients who underwent their first RTx during recent years involving treatment with current immunosuppressive regimens, we found a significantly positive effect of cyclosporine therapy, but the other predictive factors for $2-y$ posttransplant growth were similar to those found for FH in this study (13). This suggests that the identified predictive factors for $\mathrm{FH}$ may also be valid for patients today.

In conclusion, our findings show that $71-77 \%$ of the patients who received their first renal transplant before the age of 15 ended up with severely short adult stature. Revealing important predictive factors for $\mathrm{FH}$, our study is the first one to analyze the long-term influence of many factors simultaneously. It appeared that a higher $\mathrm{hSDS}_{\mathrm{CA}}$ at the time of the first RTx and AD instead of daily prednisone therapy both had a significantly positive influence on $\mathrm{FH}$, whereas a longer duration of a reduced GFR ( $\left.<50 \mathrm{~mL} / \mathrm{min} / 1.73 \mathrm{~m}^{2}\right)$ had a significantly negative effect on FH. To enhance FH, we therefore recommend treatment with biosynthetic growth hormone to improve $\operatorname{hSDS}_{\mathrm{CA}}$ at RTx $(3,4)$ and subsequent prednisone administration on $\mathrm{AD}$. The finding that long-term administration of prednisone is less growth-inhibiting when administered on $\mathrm{AD}$ is also relevant for other children requiring long-term prednisone, such as patients with chronic systemic diseases and patients who survive liver, heart, or lung transplantation.

Acknowledgments. The authors thank Dr. R. van Diemen-Steenvoorde for cooperation at the start of the study, J. Drost-van der Linden for secretarial assistance, and A. Ribbink-Goslinga for editorial assistance.

\section{REFERENCES}

1. Rees L, Greene SA, Adlard P, Jones J, Haycock GB. Rigden SPA, Preece M, Chantler $C 1988$ Growth and endocrine function after renal transplantation. Arch Dis Child 63:1326-1332

2. Van Diemen-Steenvoorde R. Donckerwolcke RA, Brackel H, Wolff ED, De Jong MCJW 1987 Growth and sexual maturation in children after kidney transplantation. J Pediatr 110:351-356

3. Hokken-Koelega ACS, Stijnen T, De Muinck Keizer-Schrama SMPF, Wit JM. Wolff ED, De Jong MCJW, Donckerwolcke RA, Abbad NCB, Bot A, Blum WF, Drop SLS 1991 Placebo-controlled, double-blind cross-over trial of growth hormone treatment in prepubertal children with chronic renal failure. Lancet 338:585-590

4. Tönshoff B, Mehls O, Heinrich U, Blum WF, Ranke MB, Schauer A 1990 Growth-stimulating effects of recombinant human growth hormone in children with end-stage renal disease. J Pediatr 116:561-566

5. Hokken-Koelega ACS, Stijnen T, de Ridder MAJ, de Muinck KeizerSchrama SMPF, Wolff ED, de Jong MCJW, Donckerwolcke RA, Groothoff JW, Blum WF, Drop SLS 1994 Growth with growth hormone treatment in growth-retarded adolescents after renal transplant. Lancet 343:1313-1317 
6. Fine RN, Yadin O, Nelson PA 1991 Recombinant human growth hormone treatment of children following renal transplantation. Pediatr Nephrol 5:147151

7. Roede MJ, Van Wieringen JC 1985 Growth diagrams 1980; Netherlands third nation-wide biometric survey. Tijdschr Soc Gezondheidszorg 63(suppl):1-34 8. Greulich W, Pyle I 1959 Radiographic Atlas of Skeletal Development of the Hand and Wrist. Stanford Press, Stanford, CA

9. Tanner JM, Whitehouse RH 1976 Longitudinal standards for height, weightheight, weight-velocity and stages of puberty. Arch Dis Child 51:170-179

10. Van de Brande JL, Van Gelderen HH, Monnens AH 1990 Endocrinologie en groeistoornissen. In: Van de Brande JL (ed) Kindergeneeskunde. Bunge, Utrecht, Germany, pp 179-219

11. Morris MC, Allanby CW, Toseland P 1982 Evaluation of a height/plasma creatinine formula in the measurement of glomerular filtration rate. Arch Dis Child 57:611-614

12. Rizzoni G, Broyer M, Brunner FP 1983 Combined report on regular dialysis and transplantation of children in Europe, XIII. In: Davison AM, Guillou PJ (eds) Proceedings of EDTA, Vol 21. Pitman, London, pp 82-88

13. Hokken-Koelega ACS, Van Zaal MAE, De Ridder MAJ, Wolff ED, De Jong MCJW, Donckerwolcke RA, De Muinck Keizer Schrama SMPF, Drop SLS 1994 Growth after transplantation in prepubertal children: impact of various treatment modalities. Pediatr Res 35:367-371
14. Pennisi AJ, Costin G. Phillips LS 1977 Linear growth in long-term renal allograft recipients. Clin Nephrol 8:415-421

15. Fennell RS, Love JT, Carter RL 1986 Statistical analysis of statural growth following kidney transplantation. Eur J Pediatr 145:86-89

16. Blum WF, Ranke MB, Kietzmann K, Tönshoff B, Mehls O 1991 Growth hormone resistance and inhibition of somatomedin activity by excess of insulin-like growth factor-binding protein (IGFBP) in uraemia. Pediatr Nephrol 5:539-545

17. Hokken-Koelega ACS, Stijnen T, De Muinck Keizer-Schrama SMPF, Blum WF, Drop SLS 1993 Levels of growth hormone, IGF-I and -II, IGFBP-1 and -3 , and cortisol in prednisone treated children with growth retardation after renal transplantation. J Clin Endocrinol Metab 77:932-938

18. Donckerwolcke RA, Chantler C, Broyer M 1980 Combined report on regular dialysis and transplantation of children in Europe, 1979. Proc Eur Dial Transplant Assoc 17:87-115

19. Potter D, Feduska N, Melzer J, Garovoy M, Hopper S, Duca R, Salvatierra O 1986 Twenty years of renal transplantation in children. Pediatrics 77:465-470

20. Broyer M, Donckerwolcke RA, Brunner FP 1983 Combined report on regular dialysis and transplantation of children in Europe, 1982. Proc Eur Dial Transplant Assoc 20:79-107

21. Broyer M, Guest G, Gagnadoux MF 1992 Growth rate in children receiving AD corticoid treatment after kidney transplantation. J Pediatr 120:721-725 